\title{
Turning Windows into Mirrors: Digital Stories as a Teaching Strategy to Explore the Apprenticeship of Observation in Pre-Service Teachers
}

\author{
Carolina S. Botha \\ COMBER, North-West University, Potchefstroom, South Africa \\ https://orcid.org/0000-0003-1693-5575
}

\begin{abstract}
This article shares the critical reflections of a teacher educator who utilised digital stories as a teaching strategy in a professional development module for final-year pre-service teachers. Action research, through a participatory narrative inquiry approach, was employed, and data were gathered from digital stories, scripts, and reflective essays. The findings suggest that a platform was created for students to collaboratively share their perceptions, beliefs, and memories regarding teaching as a profession and to reflect on the impact that this lived experience had on their developing professional identity and ideas of good practice. Suggestions are made for recognising autobiographical stories as essential to all facets of teacher education and for acknowledging the influence of the apprenticeship of observation on individual pre-service teachers and on teacher-training programme curriculums.
\end{abstract}

Keywords: apprenticeship of observation; digital stories; narrative inquiry; pre-service teachers; professional identity

\section{Introduction}

Regardless of the specific motivation individuals may have for initially deciding to study teaching, they will be confronted with a significant transition once they enter tertiary education and, subsequently, the teaching career. As early as 1975, Dan Lortie, in his apprenticeship of observation, postulated that students did not enter tertiary studies as blank slates, but instead came with a set of predetermined ideas about good practice in teaching that had a profound influence on their developing professional identity (Lortie, 1975). In 2009, Palmer et al. (2009) speculated that these perceptions and experiences that students had before they entered university might not receive the adequate academic scrutiny that they deserved and needed. 
In traditional lecture halls, students are often required to only look through windows, as they are often only confronted with the lenses of the epistemological and ontological view of the lecturer or the institution instead of being empowered to, through critical thinking and reflective practice, turn those windows into mirrors. This article reflects on a teaching strategy where space was created, through digital storytelling, for final-year pre-service teachers to explore the abovementioned aspects by unpacking their lived experience and memories that influenced their career choice and the subsequent conceptualisation of their professional identity (Gholami et al., 2021).

Stories are an effective and emotional tool to create context and to explain, understand, and share phenomena and emotions. It is a way of seeking meaning and making sense of experiences, and a positive way of creating identity. Since Schön (1983) advocated the significance of reflection for learning, many approaches have been utilised to explore teacher experience and practice and to offer a platform for the voices of teachers to be heard (Botha, 2017). Freire's (1970) theory of critical pedagogy postulates that a person's lived experience should be the foundation for learning.

This paper is grounded in the notion that autobiographical experience, memories, and life history should be recognised as essential to all facets of teacher education and that these stories have the power to influence their professional identity as future praxis. Lambert (2010, p. 10) comments that "finding and clarifying stories helps people to understand the context of their lives". This process of selfreflection helps one "move from an awareness of 'I am' to a deeper awareness of 'I have been ... I am becoming ... I am ... and I will be ...'” (Lambert, 2010, p. 10).

In line with the recommendation of Dwyer et al. (2017) and Eichsteller (2019), I choose to use the term "narrative inquiry" instead of "storytelling" when referring to the unpacking of these experiences. As rationalisation, Dwyer et al. (2017) emphasise Aristotle's use of narrative as the natural framework for representing the world of action. Narratives provide explanations of everyday sense making through stories. Within this framework, this paper, therefore, utilises digital storytelling as a form of participatory narrative inquiry to explore the apprenticeship of observation in pre-service teachers.

\section{Evidence and theories overview}

\subsection{The apprenticeship of observation}

Together with constructivist thinkers such as Piaget (1970), Lortie (1975) and Vygotsky (1978) have explored the powerful influence that prior learning and previous experiences can have on the perceptions and experiences of pre-service teachers. The notion of the apprenticeship of observation refers to the lasting influence of the years that students spent as observers as learners in schools where they formed an idea of what they thought good teaching practice was, based on what they saw their teachers doing (Lortie, 1975). These pre-conceived notions are largely one-dimensional, imaginary, unexamined, and remarkably resistant to change and do not encompass the true complexity of teaching (Botha, 2020; Darling-Hammond \& Bransford, 2005; Mewborn \& Tyminski, 2006; Reyneke \& 
Botha, 2019). Lortie (1975) warns that by only seeing what teachers do in class and not having any insight into their thinking, planning, and pedagogical decision making, pre-service teachers will most probably never connect teaching objectives and teacher actions. They may not realise that teachers are constantly making pedagogical choices between different teaching strategies or considering the various types of knowledge, skills, and values they have to convey during a lesson.

In addition, this apprenticeship of observation has an impact on and contributes to the conceptualisation of the already developing professional identity of a preservice teacher. In light of this, teacher educators may seek to provide opportunities for individual deconstruction and the unpacking of these perceptions instead of avoiding the acknowledgement of the presence of this apprenticeship in the lives of their students (Botha, 2020; Darling-Hammond, 2006). Digital stories, through the lens of participatory narrative inquiry, provide a suitable vehicle to explore these autobiographical memories of students to elicit the impact that this apprenticeship could have on their developing professional identity.

\subsection{Digital stories}

Digital life stories are grounded in critical pedagogy (Freire, 1970) and the social learning theory (Bandura, 2001), which develops the idea of modelling and selfmodelling. Such stories, according to Kim and $\mathrm{Li}$ (2020, p. 1), are three- to sixminute video vignettes through which students can "engage in critical reflection about their experiences, participate actively in the learning process, and give voice to their identities". In such videos, a first-person voiceover is used with selected visual material that has been sourced specifically to address a particular theme. Creating these stories inevitably becomes an emotive experience. Additional advantages of these stories over traditional storytelling comprise the option of including emotional and affective content through enhanced creativity and the freedom to use one's imagination, involve personal motivation, and offer opportunities for collaboration (Fleer, 2018; Lambert, 2010; Robin, 2008; Yocom et al., 2020). Further benefits identified in the literature include the user's development of personal and professional identity (Fleer, 2018; Kim \& Li, 2020), the enhancement of academic skills (Marais, 2021), such as digital searching or oral and writing, and its service as a transformative tool for a variety of contexts (Dahlström \& Damber, 2020; Kearney, 2011). Digital stories are often interdisciplinary and participatory (Robin, 2008) and have the potential to be a catalyst for great power and personal growth (Kim \& Li, 2020). This strategy is, therefore, a deliberate effort to combine technological applications with predetermined pedagogical approaches. This may include using embodied pedagogies on a real-life platform for authentic stories that portrays not only ownership of the story but also a reflection on past and future motivation and behaviour.

\subsection{Participatory narrative inquiry}

Clandinin and Rosiek (2007) build on the work of Dewey when they advocate a pragmatic ontology of experiences where all of an individual's experiences grow from other experiences that are located somewhere on the continuum of that 
person's past, present, or future. In addition, Connelly and Clandinin (2006, p. 477) highlight the following:

$[P]$ eople shape their daily lives by stories of who they and others are and as they interpret their past in terms of these stories. Story, in the current idiom, is a portal through which a person enters the world and by which their experience of the world is interpreted and made personally meaningful.

Such a participatory paradigm requires a focus on critical subjectivity where knowledge is created through critical self-reflection and reflexive dialogue (Wood, 2020). This promotes the acceptance of multiple ways of knowing, multiple realities, and an openness to alternative ways of understanding the world and contexts people live in. In addition, it creates space for narrative inquiry as a valid methodology.

Narrative inquiry thus presents a suitable vehicle for an action research approach to exploring the stories and lived experience of pre-service teachers (Ding \& Curtis, 2020). Lived experience and experiences of a specific personal and social context are explored (interaction) whilst transcending boundaries of past, present, and future (continuity). According to Bell (2002), researchers should acknowledge that stories do not exist in a vacuum but are constantly restructured and retold as new events unfold and new interpretations of older events become available. When storytelling, in this case digital storytelling, is considered as a way of participatory narrative inquiry, the content of and reflection on the story become more important than the making and telling of the story. The hidden meanings are explored, and both the storyteller (pre-service teacher) and the listener (researcher) are invited to critically reflect on their own experience and the influence of this story on their conceptualised reality. In the context of this study, digital stories are used to explore the impact of the apprenticeship of observation and the subsequent development of the professional identity of pre-service teachers. The principles of narrative inquiry were employed to answer the following research question that guided the study: How can digital storytelling be used as a participatory tool to explore the developing professional identity of pre-service teachers?

\section{Methodology}

The original intent of this digital story assignment was to explore the life stories and lived experience of participants as part of an academic module in a preservice teacher education programme. It soon became clear that there was much to be learnt from this endeavour, and the subsequent aim became to analyse these stories as a means of exploring the impact of the apprenticeship of observation on the creation of these stories. In addition, I realised that there was an opportunity to explore the value of these stories in the development of the professional identity of these pre-service teachers. As this was an activity that span several weeks, had several components, and fostered self-reflection with the goal of personal and social transformation, an action research approach was used for the study. In the following section, the methodology used during this endeavour will be unpacked by introducing the participants (the storytellers), exploring the ethics of care with 
which this research was undertaken, and sharing the process of data gathering and analysis.

\subsection{The storytellers}

The participants in the study were enrolled for an eight-credit, 12-week teaching methodology module in a pre-service teaching programme at a university in South Africa. This second-semester module is presented in the fourth and thus final year of the pre-graduate programme, and the focus of the module is the culmination of modules scaffolding professional development. The students were, therefore, expected to display the knowledge, skills, and values regarding the development of their professional identity throughout their pre-service teaching programme and teaching practice experiences at schools.

The demographic composition of the students was very diverse in terms of gender, language, and race. The cohort of the study consisted of 44 students, of which $74 \%$ were female and $26 \%$ male, and $65 \%$ spoke Afrikaans and 35\% English. Of the 44 students, 34 were white, five coloured, and five black.

\subsection{An ethics of care}

Sharing stories and experiences can be a very personal experience, and it is, therefore, crucial that a culture and a relationship of trust and mutual respect exist between the teacher educator and the students before such an activity is undertaken. Connelly and Clandinin (2006) point out that in a narrative inquiry endeavour, negotiation about respect, mutuality, and openness to include multiple voices is essential.

Building a relationship and creating rapport are essential parts of preparing for an action research endeavour. In an effort to create trust and a feeling of safety for the students to share their stories, I introduced the assignment by presenting my own digital story about the development of my professional identity as a teacher and, subsequently, as a teacher educator. I was honest and shared both the joys and the struggles I had experienced in my career thus far. I acknowledged my own apprenticeship of observation and admitted that I regarded it as both a joy and a burden that I possibly played a role in the forming of the apprenticeship of observations of my students. Sharing my own story in the format expected for the assignment served as an opportunity not only to create a safe space but also to motivate the students to share their own lived experience, expectations, and perceptions regarding teaching as a career. It also served to address power imbalances in the room.

Ethical approval for this study was obtained through the appropriate institutional channels. At the onset of the assignment, all students enrolled for the module were invited to provide informed consent should they agree to their stories being shared on the online learning platform of the university. In this way, it would be also available for other students in the class to view. Two students opted not to provide such consent. Subsequently, at the end of the semester, after grading and the marks had been released, the students were also requested to provide informed consent for their digital stories and other data resulting from this assignment to be used in the study and possible future presentations. All of the 
students provided their consent, including the two students who had not agreed to their stories being shared on the electronic platform. As a gesture of respect, I undertook not to use any of the material they had created in this paper. To guarantee anonymity, the students were offered the option of choosing pseudonyms for this paper.

\subsection{The process}

The assignment reported on in this paper was designed as a six-week activity making up the largest part of the formative assessment for the module. Students were expected to submit three separate components over the allotted time. First, a script for the envisioned digital story was submitted. After submitting the digital story and taking part in class discussions, the students submitted a reflective essay on their experience. The process was divided into four phases. These phases can be regarded as cycles in a participatory action research design. As part of a complete assignment document, the students were given the following theme for their digital story:

\section{Becoming a teacher}

Look back, look inward, or look forward ...

Reflect on the following questions and use them as inspiration for your digital story. You can choose to address only one, or more, of these issues.

Which people, events, and factors led to your decision to enrol for a teaching qualification? Which teachers or other people in your life had an influence on your career choice? How was your own experience of being a learner, and how did it influence the type of teacher that you are going to be? What are the greatest lessons that you have learnt through your years as a BEd student?

How do you experience being a BEd student? Are you still sure that you want to become a teacher? Who or what has influenced your point of view? Which factors do you currently regard as influential in the development of your professional identity?

What are your fears and concerns about your future as a teacher? Which aspects of professional development do you still need to give attention to before you will feel prepared to enter a full-time teaching position?

\subsubsection{Cycle 1: Conceptualisation}

During the first cycle, the students were tasked with only conceptualising the script of their digital story that could ultimately be used as a voiceover for their story. As a lecturer-researcher, I was cognisant of the danger of letting students get caught up in the excitement of using new technology and focusing more on the process of creating the digital story than on the content of the story. Therefore, by writing a script of 250 words as a first submission, the students were forced to concentrate their efforts on examining their own perceptions, expectations, and experiences.

After the submission of the scripts, I provided detailed individual feedback to each student, including prompting questions to foster more critical thinking and self-reflection. The students then had the opportunity to consider the feedback 
and improve their scripts, after which they started the process of creating their digital stories. I also invited the students to a face-to-face conversation, should they want to discuss any matters relating to their script or my comments.

\subsubsection{Cycle 2: Creation}

The assignment allowed the students the freedom to design the structure and content of the story to allow them to be creative and fully represent themselves in the final product. The only prerequisites were a time limit of three to five minutes and a 250-word limit on the script for the voiceover. They were given the option of using a variety of free software, such as PowerPoint with a voiceover, Animoto, MovieMaker, Videoscribe, or Powtoons. Relevant training was provided through a list of websites providing information and online facilitators. The completed digital stories were submitted via the online learning platform of the university. In as much as I dislike quantifying effort and performance, the assignments had to be graded with an analytical rubric, where different levels of achievement were awarded to a variety of assessment criteria. An analytical rubric was chosen over a holistic rubric because it tends to provide more detailed feedback, allows for consistent grading, and gave me the option of including additional comments that provided feedback on a much more personal and detailed level.

\subsubsection{Cycle 3: Sharing}

After grading, a viewing party, with soda and popcorn, was held during two classes, where the students viewed the digital stories of their peers. Before the viewing, we collaboratively negotiated house rules that, firstly, respected the privacy of the students and, secondly, fostered a caring environment where the students felt safe to share their work. After every few stories, I facilitated a conversation that started with positive feedback and appreciation for both the story and the effort that went into the making of the digital story.

\subsubsection{Cycle 4: Reflecting}

In the final cycle of the assignment, the students were tasked with writing a reflective essay in which they were invited to critically reflect on their expectations and experiences and evaluate the influence of the assignment on the conceptualisation of their developing professional identity. The reflective essays were not graded, as I did not want to assign a numeric value to this very personal form of feedback. I did, however, read each reflection and returned a personal thank-you note that validated their effort and shared how their stories had touched me and influenced my own thinking and practice.

\subsection{Data analysis}

Scripts, digital stories, rubrics, reflective narratives, observations, and notes of class discussions were used as sources of data to enhance the validity and reliability of the study. A three-phase inductive approach, consisting of preparing, organising, and reporting, was followed to analyse the data. The preparation involved a decision to use words and sentences as the unit of analysis. I attempted to make sense of the data by reading several times through all the data and attempting to identify themes. Organising the data was initiated through open coding, and then the data were analysed using content analysis, one of the qualitative research techniques. 
To ensure justice, beneficence, and respect, I shared my findings and subsequent themes with the students via a forum discussion on the online learning platform. They were invited to do member checking and contribute to the process of ensuring the validity of the data. This was valuable to assure outcome validity (in acknowledging unexpected outcomes), dialogic validity (to ensure that all of the participants felt that their voices were heard and their contribution acknowledged), democratic validity (in that we followed a collaborative process throughout the study), and process validity (that the core principles of action research were adhered to).

During the conceptualisation of this paper, I expected to use several excerpts from various stories to illustrate the themes that had been identified. But I eventually made the decision to share the full scripts of four students instead of sharing isolated excerpts from various students' work. This is intended to facilitate a more detailed narrative and thereby capture the context and emotion shared in their digital stories. In addition, such an approach provides a more lifelike and authentic view of the data and invites the reader into the holistic experience of individuals. The digital stories of Alicia, Mary, Rene, and Pieter (pseudonyms) are shared in the next section. Their reflective narratives were also utilised in the data shared in this study.

\section{Sharing in some stories}

Through thematic analysis, the following themes of the digital stories and in other supporting data sources were identified:

- Academic excellence

- Empathetic caring

- Tradition

- Empowering mentorship

\subsection{Academic excellence: Alicia's story of being inspired}

When I was at school, I had teachers who were not very, how shall I put it, enthusiastic about their subjects. They would rather sit behind their desk while they left us to our own devices. I do not want to be that type of teacher. I choose to remember the teachers who inspired me and who had a great influence on my life. My Hospitality Studies teacher inspired me to become a teacher. In her classes I found my passion. She was always prepared and ready to give advice. Once I started my teaching studies, she was the mentor for my first teaching practice. She really took me under her wing and showed me the other side of being a teacher.

I was astounded at her subject knowledge. It was so much more than what I realised when I was a learner in her class. I want to be that type of teacher. A subject specialist. A lifelong learner. I want to give them a reason to work hard at academics. I think academic teaching is the primary job of a teacher and we have a responsibility to foster a love for learning in children.

We must set the example of academic excellence. Like my Hospitality Studies teacher did. 


\subsection{Empathetic caring: Mary's story of overcoming being bullied}

I was bullied at school. I felt alone, no one wanted to help me. My life was useless. They called me names and said there's nothing I can do about it ... if I do, they will tell everybody I am the school slut. How could you ruin someone's life like that?

People just kept saying "Be the strong one ...", "Be happy, it's not the end of the world." How can you say this to a child? My world is falling apart, and you DON'T even see it! It felt like the whole school was against me. At break time I would sit in the classroom, just to avoid the people.

One day a teacher came to me and said she was worried. That day she adopted me and started treating me like her own daughter. Made me feel self-worth. She never gave up on me.

I was more at peace because I knew someone at school was looking after me. Because of that one teacher, the one person who saw me as me, and who saw that I did not fit in, I wanted to become the best teacher that I could be. For the children like me, the losers, the outsiders. To remind them that there is a plan for each and every one of them.

I am looking forward to becoming a teacher, to journey with the misunderstood children until they also find a reason to live. I will succeed!

\subsection{Tradition: Rene's story of filling big shoes}

I come from a family of teachers. My grandfather was a school principal. My mother and father are both still teachers. I did not have much of a choice for my career. It almost feels like I have been teaching my dolls since I was in nappies myself. I am very proud of my family history. Although it sometimes feel[s] as if my identity has been imprinted on me without giving me the choice to choose another path. I have big shoes to fill.

I, however, admit that my first opportunities to stand in front of a class during teaching practice have given me a new founded respect for this family tradition. They made it look so easy. I am quickly learning that it is not. I never realised how much work goes into being a teacher. I thought all that you needed was a love for children and a desire to change lives.

Teaching practice taught me that being a teacher is very time-consuming. Don't think your day is over when the school bell rings. I never thought about when marking happened, and I never realised how much planning one had to do before a lesson. This was indeed an eye-opener! So I am very grateful for the shoulders of giants that I can stand on. I know they will be there to guide me when my time comes.

\subsection{Empowering mentorship: Pieter's story of overcoming adversity}

I had to work very hard while I was at school. I have a learning disability. But I received so much extra support and encouragement from my teachers. I thought that I would never be able to become a teacher myself, I was not meant to go to university. But my rugby coach instilled faith in 
myself that was not rooted in marks on a report card. He was there to support me when I was sad about a poor report card or overjoyed after scoring a winning try. He taught me that a great teacher did more than teach academics, he invested in his learners. He saw past their adversities and embraced their potential. He helped them to believe in themselves.

I struggled with the transition of moving between school and university. It took me a few years longer than my peers to get it done. I failed some subjects along the way, but I will eventually be graduating at the end of this year. I found my feet and learnt the tricks of the trade.

I want to start teaching to be a mentor to children like me, who felt dumb and disabled and like a disappointment. I want to help them see that anything is possible, if they just believe and work hard enough.

\section{Discussion}

\subsection{A snapshot of identity in time}

I found great joy in watching the variety of digital stories with my students. The true privilege and value of participatory work were, however, the facilitation of the reflective discourses and the subsequent identification of four very strong themes emerging from their efforts. I found pleasure in hearing students collaboratively deconstructing their thought processes and sharing in the emotions behind the stories. In her reflective essay, Rene linked her experience to that of her peers and the stories she had learnt from them:

I have always felt very emotional when I heard the reasons people was inspired to become teachers. In my situation I never had that 'wow' moment. It was a given. But for the first time I really understand how to translate my own feelings and thoughts into being a good teacher.

It was almost like being invited into someone's home after initially only having been allowed to look in through a window. The digital stories portrayed the outside façade of the house, but the discourse and reflective essays invited the reader in. Mary's courage to share her story of being bullied and marginalised created a platform for other students to share their difficult stories as well. Having courageous conversations about what had happened in their past or even what they were going through at that very moment contributed to the group of students having empathy for one another and committing to an awareness of such issues in their future careers. This added depth and insight to the reflective essays that were written after those conversations during the viewing parties.

Although the themes were visible in almost all of the stories, comparing and contrasting the content of class discussions and reflective essays also provided valuable insight. It was interesting to note, in the tradition of narrative inquiry, that the continuity of time was prominent. Almost all of the stories had a component of reflection on the influence of the past on their decision to study teaching. They also included a realistic component of the present time, indicating that they all had more to learn and realised that they still needed more preparation to become the great teachers they envisioned to be in their future. Pieter's story is 
a good example of the influence of time on his story of becoming a teacher. In his reflective essay, he explains:

I never thought I would look back to my difficulties at school and be grateful for what it has taught me. Making this digital story helped me to see that my past does still have an influence on my future, but in a good way, and that I have the power to dictate the terms of that influence on my future.

However, I had to ask myself how critical these reflections on past experiences were. Were the students, in the script of their digital stories, merely sharing experiences from the past, or were they possibly acknowledging the influence of the apprenticeship of observation on their perceptions of what teachers did on a daily basis? This study begs the question of whether the students might have lived and relived these stories for years, but maybe then, for the first time, they might really understand the true impact of the story on not only their career choice but also the development of their professional identity. Could the class discussions and reflective essay support these students' attempt at linking context and time for professional development? The new meaning that they had made had the potential to transform thinking and empower them.

I could clearly see the impact of the apprenticeship of observation on their perception of good teaching practice, personal mentoring, or empowering learners. As the creators of their stories, many of the students recognised that past experiences not only shaped their current practice but also defined their visions of career development grounded in specialised subject knowledge, student mentoring, or a love of learning. The stories also showed that the final-year preservice teachers held particular ideas about teaching and learning that paralleled the practices they themselves had experienced and how they aimed to engage their own learners in a passion for their chosen discipline. The love for teaching that Alicia's hospitalities studies teacher had instilled in her reminds one of the vital role that teachers play in the holistic development and support of learners. Individual teachers have the power to inspire and instil a passion for learning and teaching that can have a lasting impression on their personality, career, and overall being.

After holding the viewing parties and analysing the reflective essays, I was, however, still unclear on whether the ways in which the influence of the apprenticeship of observation was illuminated were intentional or incidental. As both a teacher educator and a researcher, I was not sure whether the deeply ingrained influence of the apprenticeship had truly been deconstructed through the process. Was there a deliberate decision and effort to overcome this influence, or might the students now only be more aware of the existence of this apprenticeship? Table 1, through reference to the digital stories and reflective essays of the students whose stories are shared in this paper, explores the challenges that the apprenticeship of observation possibly still poses for preservice teachers. 


\subsection{Exposing the challenges of the apprenticeship of observation}

Table 1: Challenges posed by the apprenticeship of observation

\begin{tabular}{|c|c|c|}
\hline $\begin{array}{l}\text { Challenges } \\
\text { posed by the } \\
\text { apprenticeship } \\
\text { of observation }\end{array}$ & $\begin{array}{c}\text { Implication for the } \\
\text { development of professional } \\
\text { identity and teaching } \\
\text { practice }\end{array}$ & $\begin{array}{l}\text { Evidence of this challenge from } \\
\text { digital stories or reflective essays }\end{array}$ \\
\hline $\begin{array}{l}\text { Perceptions of } \\
\text { teaching are } \\
\text { based on only } \\
\text { their own } \\
\text { preferences, } \\
\text { needs, and } \\
\text { experiences }\end{array}$ & $\begin{array}{l}\text { Pre-service teachers may not } \\
\text { have an extensive } \\
\text { understanding of teaching } \\
\text { strategies and interventions } \\
\text { for children who learn in } \\
\text { different ways (learning } \\
\text { styles, challenges, etc.) than } \\
\text { they do. They may teach in } \\
\text { ways that work for } \\
\text { themselves instead of what } \\
\text { other individuals may need. }\end{array}$ & $\begin{array}{l}\text { "This assignment taught me that not } \\
\text { all learners who struggle will have the } \\
\text { same needs that I did." (Mary) } \\
\text { "I have to learn that a good teacher } \\
\text { cannot teach all learners in the same } \\
\text { way. I never realised that when I was } \\
\text { experiencing my own learning } \\
\text { difficulties." (Pieter) }\end{array}$ \\
\hline $\begin{array}{l}\text { Concept of good } \\
\text { and bad practice } \\
\text { is limited to that } \\
\text { which they had } \\
\text { seen when they } \\
\text { were in school }\end{array}$ & $\begin{array}{l}\text { Without first-hand experience } \\
\text { of alternative teaching } \\
\text { approaches, pre-service } \\
\text { teachers may lack the } \\
\text { knowledge and the will to } \\
\text { move beyond the models } \\
\text { they have experienced, which } \\
\text { are very often teacher- } \\
\text { centred. }\end{array}$ & $\begin{array}{l}\text { "I now only realise that what I } \\
\text { considered good teaching might not } \\
\text { necessarily have been that good. I now } \\
\text { see how teacher-centred my teachers at } \\
\text { school were and I might have more } \\
\text { innovative ways to teach the same } \\
\text { material." (Alicia) }\end{array}$ \\
\hline $\begin{array}{l}\text { Only obtain a } \\
\text { partial view of } \\
\text { the complexity } \\
\text { of teaching; } \\
\text { students are not } \\
\text { aware of the } \\
\text { thought } \\
\text { processes } \\
\text { involved in the } \\
\text { planning, } \\
\text { preparation, and } \\
\text { teaching of } \\
\text { lessons }\end{array}$ & $\begin{array}{l}\text { Differentiation techniques by } \\
\text { which teachers engage } \\
\text { learners in different activities } \\
\text { or assignments based on } \\
\text { students' unique interests, } \\
\text { learner preferences, or needs } \\
\text { are obscured in the } \\
\text { apprenticeship of } \\
\text { observation. Pre-service } \\
\text { teachers oversee these } \\
\text { complexities during teaching } \\
\text { practice when they are just } \\
\text { attempting to cope. }\end{array}$ & $\begin{array}{l}\text { "I thought I knew what being a } \\
\text { teacher encompassed. But it took } \\
\text { teaching practice and this assignment } \\
\text { to realise that I might have } \\
\text { romanticised the career. I grew up } \\
\text { amongst teachers but I didn't really } \\
\text { have an idea how hard they worked." } \\
\text { (Rene) }\end{array}$ \\
\hline $\begin{array}{l}\text { Underestimate } \\
\text { the } \\
\text { administrative } \\
\text { load }\end{array}$ & $\begin{array}{l}\text { As learners, and even as pre- } \\
\text { service teachers, students } \\
\text { only receive graded papers } \\
\text { without being aware of the } \\
\text { time it takes to grade these } \\
\text { and the great administrative } \\
\text { burden that is continuously } \\
\text { placed on teachers. }\end{array}$ & $\begin{array}{l}\text { "As a child you never wonder when } \\
\text { that teacher marked your test. As a } \\
\text { student teacher I suddenly realised } \\
\text { that these things happened at night } \\
\text { and at a great cost to the personal live } \\
\text { and family of a teacher." (Alicia) }\end{array}$ \\
\hline $\begin{array}{l}\text { Underestimate } \\
\text { the different } \\
\text { roles teachers } \\
\text { play }\end{array}$ & $\begin{array}{l}\text { Pre-service teachers are not } \\
\text { always aware of the various } \\
\text { roles that teachers play. They } \\
\text { often think that the subject } \\
\text { specialist, assessor, and }\end{array}$ & $\begin{array}{l}\text { "I saw the job of a teacher as teaching, } \\
\text { coaching sport and sometimes helping } \\
\text { a child in need. I never knew about } \\
\text { other tasks like being an agent of } \\
\text { change in the community, managing }\end{array}$ \\
\hline
\end{tabular}




\begin{tabular}{|l|l|l|}
\hline & $\begin{array}{l}\text { pastoral role are the only } \\
\text { roles of the teacher. }\end{array}$ & $\begin{array}{l}\text { diversity and inclusivity, and } \\
\text { addressing democracy and other } \\
\text { political issues." (Mary) }\end{array}$ \\
\hline $\begin{array}{l}\text { Underestimate } \\
\text { the emotional } \\
\text { toll of teaching }\end{array}$ & $\begin{array}{l}\text { Pre-service teachers are often } \\
\text { only exposed to academic } \\
\text { interaction with learners and } \\
\text { are not exposed to the } \\
\text { personal challenges teachers } \\
\text { may experience. }\end{array}$ & $\begin{array}{l}\text { the stress of their job. When they were } \\
\text { at home, they were there for me. I now } \\
\text { only respect them even more." (Rene) }\end{array}$ \\
\hline $\begin{array}{l}\text { Underestimate } \\
\text { the gap between } \\
\text { theory and } \\
\text { practice }\end{array}$ & $\begin{array}{l}\text { Many pre-service teachers } \\
\text { reported that they expected } \\
\text { that teaching would be as } \\
\text { teaching practice, and in their } \\
\text { observation, beginner } \\
\text { teachers were doing just as } \\
\text { well as veteran, experienced } \\
\text { teachers. } \\
\text { It does, however, seem that } \\
\text { during times of stress, they } \\
\text { fall back on apprenticeship } \\
\text { instead of what they learnt at } \\
\text { university. }\end{array}$ & $\begin{array}{l}\text { everything falls into place. I suspect } \\
\text { that I will have a lot of challenges to } \\
\text { overcome when I start teaching next } \\
\text { year. What if university has not } \\
\text { taught me enough? I can't rely on } \\
\text { what I thought I knew." (Alicia) } \\
\text { "I spend a lot of time planning } \\
\text { lessons. But the moment I start } \\
\text { struggling with classroom discipline } \\
\text { or things start going wrong, I forget } \\
\text { all the cool teaching strategies I learnt } \\
\text { at university and I grab a textbook. } \\
\text { Because experience tells me that is } \\
\text { what works." (Pieter) }\end{array}$ \\
\hline
\end{tabular}

\section{Turning the window into a mirror}

I experienced the joy of joining my students to look through the windows of their digital stories and then had the privilege to be invited into some homes. A true reflective practitioner, however, will not only observe the new house in which he or she is standing, but will turn that window into a mirror and utilise the opportunity to explore and improve his or her own praxis. Thus, I had to acknowledge the complexities of this assignment and be open to critical reflection and feedback. In this manner, I was also confronted with my own apprenticeship of observation and the role that I played in contributing to the apprenticeship of my students. I had to be willing to deconstruct and disrupt my own perceptions, beliefs, and expectations of teaching. This process also included gaining an acute awareness of addressing issues of diversity and inclusivity in my classes. I had to acknowledge the importance of modelling good practice to the pre-service teachers under my tutelage and critically reflect on my successes and failures in this regard.

I was invited to look in the mirror at my own identity, my own story, and my own house and acknowledge the new knowledge I had gained and the meaning I had made through this endeavour. This assignment not only challenged my students to critically unpack their understanding of their identity as teachers and to reevaluate their own epistemological and ontological positioning, but I was challenging myself to do so as well. I had to critically assess the learning from this assignment in my own teaching and learning practice and explore the implications of this for the greater initial teacher education programme. 


\section{Implications for practice}

It is generally accepted that pre-service teachers struggle once they stand in fulltime teaching positions. The data from this study have shown that the influence of the apprenticeship of observation cannot be overlooked. Teacher educators have the responsibility to assess the curriculum of their modules and programmes to invite stories and lived experience into their classrooms. Adopting an action research approach to teaching will not only enhance and develop the scholarship of teaching and learning of the teacher educator but also acknowledge and address the apprenticeship of observation in both the student and the teacher educator.

It was clear that there were, in essence, two narratives in each digital story - the overt narrative heard in the voiceover and the hidden message that not even the creator of the story might have been aware of. The reflective essays were valuable in identifying these hidden stories. Teacher educators should be acutely aware of their role as facilitators of such hidden narratives. Apart from facilitating critical thinking skills as a graduate attribute in their students, they also have the responsibility of motivating and guiding students to become reflective practitioners. Narrative inquiry and storytelling allow students the opportunity for reflecting, considering alternative views and possibilities, and engaging in participatory methodologies designed to assist in the process of developing an ethical professional identity and eventually becoming agents of change in their schools and classrooms. When the teaching in university lecture halls is relevant, authentic, and meaningful, pre-service teachers can be exposed to a new apprenticeship that will enable them to provide the same atmosphere in their own classrooms where space is created for diversity, inclusivity, creativity, and individuality of all.

\section{Conclusion}

This endeavour has taught me that by encouraging pre-service teachers to value the stories they are living and the stories they hear, they may become teachers who create conditions that will allow their learners to reflect on their own stories, and by deconstructing the meaning and lived experience they bring, they may cultivate a classroom where personal growth and development are at the fore. This assignment has enhanced my own teaching practice, and I am now cognisant of always attempting to include some of the following outcomes in all my assignments:

- Create space for new meaning, new knowledge, and new understanding.

- Embrace diversity and inclusivity, and invite individual voices.

- Promote self-reflection and critical thinking.

- Enhance active learning and focus on alternative ways of teaching.

- Foster a sense of transformation and growth.

- Develop a sense of urgency for becoming agents of change in the educational landscape.

- Continuously conceptualise a professional identity that is built on the foundation of integrity, ethical behaviour, and good practice. 
Through this adventure, I was not only invited to look through a window, but I was also given the opportunity to turn that window into a mirror. I was offered the chance to not only look at the façade of student teachers' houses through the digital stories they had created, but I could also join in their search for the professional identity that supported their vision of being a teacher. Moreover, I could observe how the window turned into a mirror and invited me to critically reflect on my own identity and practice.

\section{References}

Bandura, A. (2001). Social cognitive theory: An agentic perspective. Annual Review of Psychology, 51, 1-26. https://doi.org/10.1146/annurev.psych.52.1.1

Bell, J. S. (2002). Narrative inquiry: More than just telling stories. TESOL Quarterly, 36(2), 207-2013. https://doi.org/10.2307/3588331

Botha, C. S. (2017). Using metaphoric body-mapping to encourage reflection on the developing identity of pre-service teachers. South African Journal of Education, 37(3), 1-12. https:// doi.org/10.15700/saje.v37n3a1377

Botha, C. S. (2020). The impact of the apprenticeship of observation on preservice teachers' perceptions of teaching. Journal of Education, 81, 50-64. https:// doi.org/10.15700/saje.v37n3a137710.17159/2520-9868/i81a03

Clandinin, D. J., \& Rosiek, J. (2007). Mapping a landscape of narrative inquiry: Borderland spaces and tensions. In D. J. Clandinin (Ed.), Handbook of narrative inquiry: Mapping a methodology (pp. 35-75). Sage. https://doi.org/10.4135/9781452226552.n2

Connelly, F. M., \& Clandinin, D. J. (2006). Narrative inquiry: A methodology for studying lived experience. Research studies in Music Education, 27, 44-54. https:// doi.org/10.1177/1321103×060270010301

Dahlström, H., \& Damber, U. (2020). Meanings made in students' multimodal digital stories: Resources, popular culture and values. Designs for Learning, 12(1), 45-55. https://doi.org/10.16993/dfl.145

Darling-Hammond, L. (2006). Constructing 21st-century teacher education. Journal of Teacher Education, 57(3), 300-314. https:// doi.org/10.1177/0022487105285962

Darling-Hammond, L., \& Bransford, J. (2005). Preparing teachers for a changing world: What teachers should learn and be able to do. Jossey-Bass. https://doi.org/10.5860/choice.43-1083

Ding, F., \& Curtis, F. (2020). 'I feel lost and somehow messy': A narrative inquiry into the identity struggle of a first-year university student. Higher Education Research $\mathcal{E}$ Development, 40(6), 1146-1160. https://doi.org/10.1080/07294360.2020.1804333

Dwyer, R., Davis, I. D., \& Emerald, E. (2017). Narrative research in practice: Stories from the field. Springer. https://doi.org/10.1007/978-981-10-1579-3

Eichsteller, M. (2019). There is more than one way - A study of mixed analytical methods in biographical narrative research. Contemporary Social Science, 14(3), 447-462. https://doi.org/10.1080/21582041.2017.1417626

Fleer, M. (2018). Digital animation: New conditions for children's development in playbased setting. British Journal of Educational Technology, 49(5), 943-958. https://doi.org/10.1111/bjet.12637

Freire, P. (1970). Pedagogy of the oppressed. Continuum. https://doi.org/10.5958/2231458x.2015.00027.5

Gholami, K., Faraji, S., Meijer, P. C., \& Tirri, K. (2021). Construction and deconstruction of student teachers' professional identity: A narrative study. Teaching and Teacher Education, 97. https://doi.org/10.1016/j.tate.2020.103142 
Kearney, M. (2011). A learning design for student-generated digital storytelling. Learning, $\begin{array}{llll}\text { Media and Technology, 36(2), 169-188. } & \text {. }\end{array}$ https://doi.org/10.1080/17439884.2011.553623

Kim, D., \& Li, M. (2020). Digital storytelling: Facilitating learning and identity development. Journal of Computers in Education, 8(2), 33-61. https://doi.org/10.1007/s40692-020-00170-9

Lambert, J. (2010). The digital storytelling cookbook. Digital Diner Press.

Lortie, D. (1975). Schoolteacher: A sociological study. University of Chicago Press. https://doi.org/10.1177/019263657505939422

Marais, E. (2021). A journey through digital storytelling during Covid-19 students preparedness to use technology for learning in the language classroom. Research in Social Sciences and Technology, 6(2), 169-182. https://doi.org/10.46303/ressat.2021.17

Mewborn, D. S., \& Tyminski, A. M. (2006). Lortie's apprenticeship of observation revisited. For the Learning of Mathematics, 2(3), 30-32.

Palmer, M., O'Kane, P., \& Owens, M. (2009). Betwixt spaces: Student accounts of turning point experiences in the first-year transition. Studies in Higher Education, 34(1), 3754. https://doi.org/10.1080/03075070802601929

Piaget, J. (1970). Genetic epistemology. W. W. Norton. https:// doi.org/10.7312/piag91272

Reyneke, E. M., \& Botha, C. S. (2019). The professional orientation of first year student teachers in a non-placement work-integrated learning program. International Journal of Work-Integrated Learning, 21(3), 303-316.

Robin, B. (2008). Digital storytelling: A powerful technology tool for the 21st century classroom. Theory into Practice, 47(3), 220-228. https://doi.org/10.1080/00405840802153916

Schön, D. (1983). The reflective practitioner: How professionals think in action. Basic Books.

Vygotsky, L. (1978). Mind in society: The development of higher psychological processes. Harvard University Press.

Wood, L. (2020). Participatory action learning and action research: Theory, practice and process. Routledge. https://doi.org/10.4324/9780429441318

Yocom, D., Bashaw, C., Price, D., \& Cook, M. (2020). Perceptions of digital storytelling in the classroom. Teaching and Learning in Nursing, 15(3), 164-197. https://doi.org/10.1016/j.teln.2020.01.010 